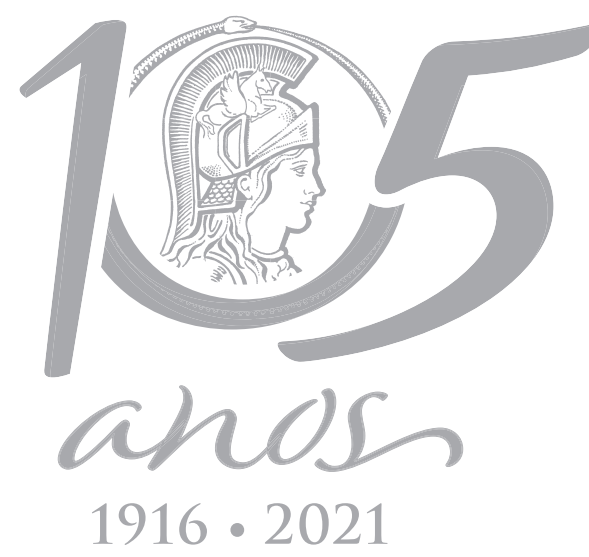

\title{
ECOSYSTEMS
}

\section{Influence of the chlorophyll-a gradient on the community structure of plankton microcrustaceans (Cladocera and Copepoda) in a Neotropical reservoir}

\author{
VANESSA G. TIBÚRCIO, TATIANE MANTOVANO, JOÃO V.F. DA SILVA \& \\ CLAUDIA C. BONECKER
}

\begin{abstract}
Fish farming in net cages is considered as an alternative to food production in response to elevated population growth, and zooplankton is an important resource to the development of this economic activity. We (i) compared microcrustacean composition in eutrophic and oligotrophic habitats under net tank influence, (ii) investigated changes in species distributions in these habitats, and (iii) indicated which chlorophyll-a concentrations presented thresholds that alter community structure. We expected different responses of species to changes in chlorophyll-a concentration due to net cage management, as chlorophyll-a represents an estimate of food availability. Microcrustacean samplings and chlorophyll-a estimation were made upstream, downstream and close to the net cages, during 120 days, in the Rosana Reservoir (Brazil). Species composition differed significantly $(p<0.05)$ among habitats where in the eutrophic environment was found the largest number of species. However, only in the eutrophic habitats did frequency of occurrence and relative abundance of some species change with chlorophyll-a variation. Thus, net cage management influenced species distribution only in the most productive habitat. These responses can affect ecosystem processes related to trophic dynamics as secondary productivity and nutrient cycling.
\end{abstract}

Key words: zooplankton, primary productivity, trophy reservoir, anthropic activity.

\section{INTRODUCTION}

Net cage fish farming in reservoirs is considered as a promising alternative to meet the increasing need for food of the world population (Alves \& Baccarin 2005, Dias et al. 2011, Tiburcio et al. 2015). The increase of this activity is related to the exploitation of available reservoirs and lakes, high efficiency in management, readiness of fish removal and continuous water flow that would theoretically improve the water quality inside the cages and reduce the production costs (Cyrino \& Kubtiza 1996, Furlaneto et al. 2006, Halwart et al. 2007).
Nonetheless, studies have pointed that this activity causes various impacts that may lead to environmental degradation in the ecosystems where they are implanted due to increased productivity (Santos et al. 2009, Borges et al. 2010, Dias et al. 2011, Tiburcio et al. 2015). Fish farming employs a considerable volume of food input to fish production in reduced space and at high density, with consequent release of food remains and metabolites directly in the environment. This characterizes fish farming as a potential source of environmental impact (Beveridge 2004). Changes in nutrient loads in these systems due to food input 
alter phytoplankton composition and cause increasing issues in these environments (Chorus \& Bartram 1999, Codd et al. 2005, Borges et al. 2010, Simões et al. 2015).

Among the aquatic communities, plankton microcrustaceans (cladocerans and copepods) may be influenced by chlorophyll-a concentration and act as an indicator or substitute group for these conditions (Mantovano et al. 2019) in environments with fish net cages. These organisms play important functional roles in aquatic ecosystems (Lemke \& Benke 2009) as they consume small algae and, when predated, transfer this energy to superior trophic levels (Lemke \& Benke 2009). Furthermore, due to variation in feeding habits (carnivores, omnivores and herbivores) (Tõnno et al. 2016), they reflect responses to environmental variation as changes in quality and density of available resources (Perbiche-Neves et al. 2016).

In this context, a group of species may be used as an indicator or substitute of other in an ecosystem, due to variation in chlorophyll-a concentration (Schwind et al. 2017, Mantovano et al. 2019). Different studies demonstrated threshold responses of species to limiting factors (Cao et al. 2016, Schwind et al. 2019, Mantovano et al. 2019). Ecological thresholds are tools used to capture changes in attributes of biological communities along an environmental gradient (Baker \& King 2010).

Admitting that threshold prediction brings benefits to ecosystem services and goods (Martin et al. 2009) and that the identification of potential thresholds is an important aspect to the management of ecological systems, we aimed to i) compare microcrustacean species composition (cladocerans and copepods) in eutrophic and oligotrophic habitats under net tank influence in a neotropical reservoir, (ii) determine changes in frequency of occurrence and relative abundance of species that occur in these habitats, and (iii) evaluate how chlorophyll-a concentration presents thresholds that alter community structure for these microcrustaceans. We expected different responses of these organisms to changes in phytoplankton biomass, estimated by chlorophyll-a concentration, once these algae are one of their main resources. Thus, we expect that species will present different distribution thresholds in both habitats.

\section{MATERIALS AND METHODS}

\section{Study area}

Samples were collected between April and August 2006 in the Rosana Reservoir (22 ${ }^{\circ} 36$, S, $52^{\circ} 49^{\prime}$ 'W) located in the lower section of the Paranapanema River (Fig. 1), inserted in the border between the states of São Paulo and Paraná, Brazil. Because this is the last dam in a reservoir cascade, it presents high water transparency and alkalinity, and low total phosphorous and nitrogen concentrations (Pagioro et al. 2005). This reservoir has an area of $220 \mathrm{~km}^{2}$, total length of $116 \mathrm{~km}$, volume of $1,92010^{6} \mathrm{~km}^{3}$, annual mean flow rate of $1,203 \mathrm{~m}^{3} \mathrm{~s}^{-}$ ${ }^{1}$ and inundated area of 27,600 ha (Cesp 1998). It is classified as oligo- mesotrophic and presents an elongated conformation, with small affluent arms and banks of submerged and rooted macrophytes (Júlio Júnior et al. 2005).

This study was developed in two arms of the Rosana Reservoir (Guairacá and Corvo Rivers). The Guairacá River, located in the lentic region of the reservoir, presents its margins with grasslands, predominantly sugar cane plantations, as well as banks of Egeria najas, Egeria densa and Eichhornia azurea. Furthermore, there is a strong influence of the wind on the horizontal circulation of water masses. The site where net cages are installed, next to the confluence with the Paranapanema River, may be characterized 


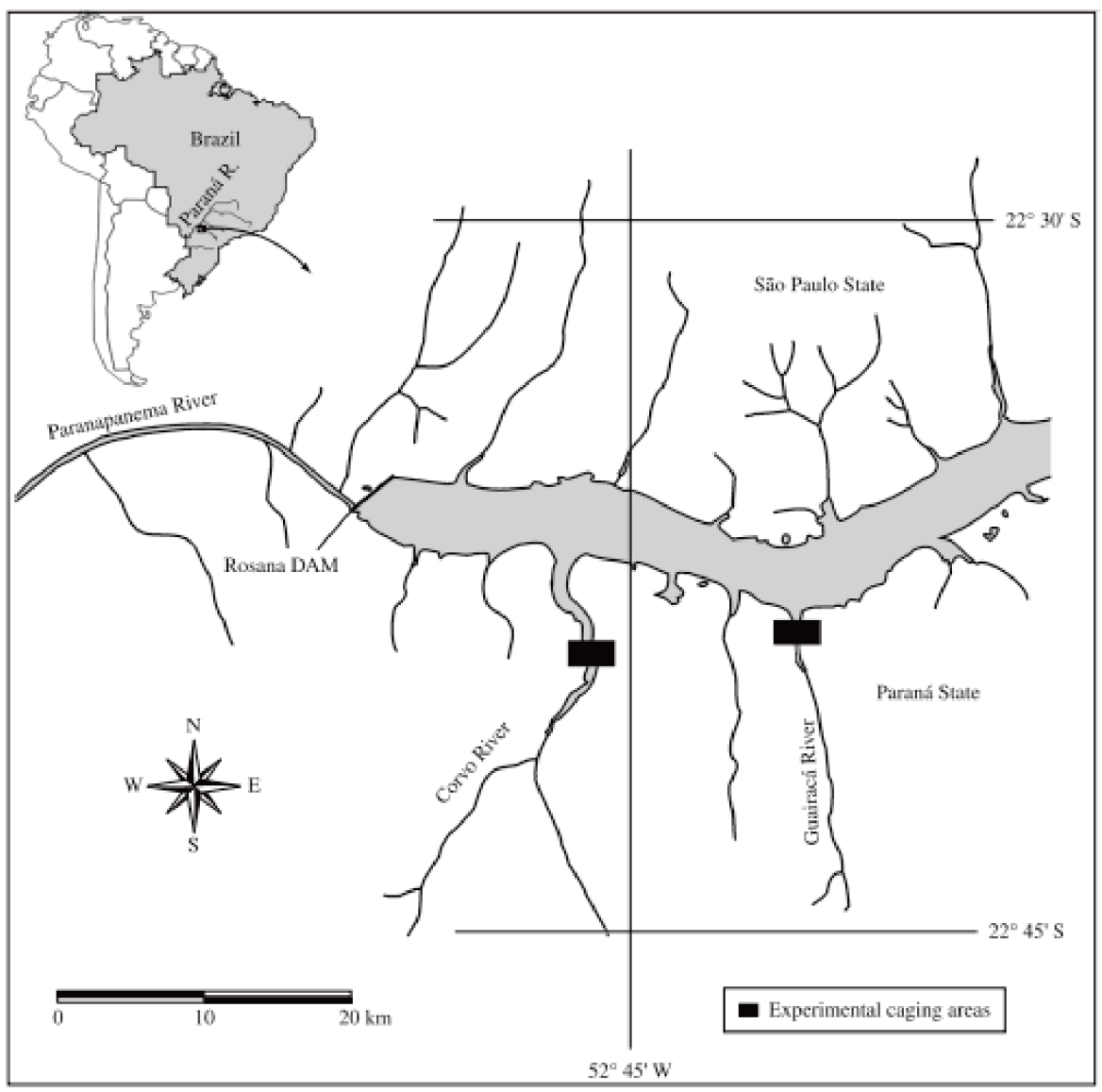

Figure 1. Map of the study area, highlighting the Guairacá and Corvo Rivers, in the Rosana Reservoir, near the confluence with the Paranapanema River (PR-SP). as oligotrophic (Borges et al. 2010). The Corvo River has its margins constituted of grasslands and initial states of reforestation, apart from a starch industry, and presents eutrophic characteristics (Borges et al. 2008). This industry possibly contributes with manioc residuals to the environment. In this river, the experiment was installed at a distance of $5 \mathrm{~km}$ from the confluence with the Paranapanema River. This affluent is situated close to the dam of the reservoir, in Paraná State, between the towns of Diamante do Norte and Terra Rica.

\section{Sampling design}

In each tributary, sampling was performed before the installation of the net cages, with different fish stocking densities (Fig. 2), in triplicates, containing five sampling points site where net cages were installed (P1), two upstream distances (P6, P7) and two downstream distances $(\mathrm{P} 4, \mathrm{P} 5)$. After this phase, two points were added to where net cages were installed (P2, P3) (Fig. 2 ), which were also sampled in triplicates. The following samplings were obtained in a period of 120 days, between April and August 2006, thus distributed: with 15 days, 30 days, 60 days, 90 days and 120 days, resulting in 120 samples in each habitat ( $n=240)$.

Microcrustaceans were sampled at the subsurface of the pelagic region, in the morning period, with a motor pump and plankton net of $68 \mu \mathrm{m}$. 200 litters of water were filtered per sample. The sampled material was conditioned in polyethylene flasks, properly labeled and fixed in formaldehyde solution at $4 \%$ buffered with calcium carbonate. 
Species identification was made with specialized literature (Koste 1978, Dussart 1984, Reid 1985, Elmoor-Loureiro 1997, Santos-Silva 2000, Lansac-Tôha et al. 2002). The abundance of individuals was estimated by analyzing a minimum of three subsamples in a SedgewickRafter chamber using an optical microscope (Bottrell et al. 1976). Samples that contained a reduced number of individuals were counted integrally.

Together with microcrustacean samplings, water samples were collected at the subsurface and kept under refrigeration for chlorophyll-a analysis, considered as an estimate of phytoplankton biomass (primary productivity) and source of resource to microcrustaceans. Chlorophyll-a concentration was determined by filtering aliquots of water in glass fiber filters (Whatman GF/F), extracting the pigments with acetone $90 \%$ and reading a spectrophotometer (663 and 775 nanometers), and was processed according to the methodology presented by Golterman et al. (1969). Calculations were performed according to the formula described in Wetzel \& Likens (1991).

\section{Data analysis}

Species frequency of occurrence was calculated according to Omori \& Ikeda (1984), with the formula Fo $=$ Ta $X 100 /$ TA, where Fo = frequency of occurrence, $\mathrm{Ta}=$ number of samples containing the species, and $\mathrm{TA}=$ total number of samples. Results were expressed as very frequent (>80\%), frequent $(40 \%-80 \%)$, little frequent $(20 \%-40 \%)$ and sporadic $(<20 \%)$.

To test whether the composition of the zooplankton communities differed significantly among the studied habitats (Guairacá and Corvo Rivers), we performed a multivariate analysis of permutation variance (PERMANOVA). We constructed a dissimilarity matrix with the Jaccard method and ran the analysis using function adonis of the vegan package (Oksanen et al. 2018) in the R environment, version 3.4 ( $R$ Development Core Team 2018).

We identified the chlorophyll-a concentration threshold, responsible for the abrupt changes in the frequency of occurrence and relative abundance of species, using the Threshold Indicator Rate Analysis (TITAN; Baker \& King 2010). TITAN allowed us to identify the limits or points of change for each taxon and for the whole community along the environmental

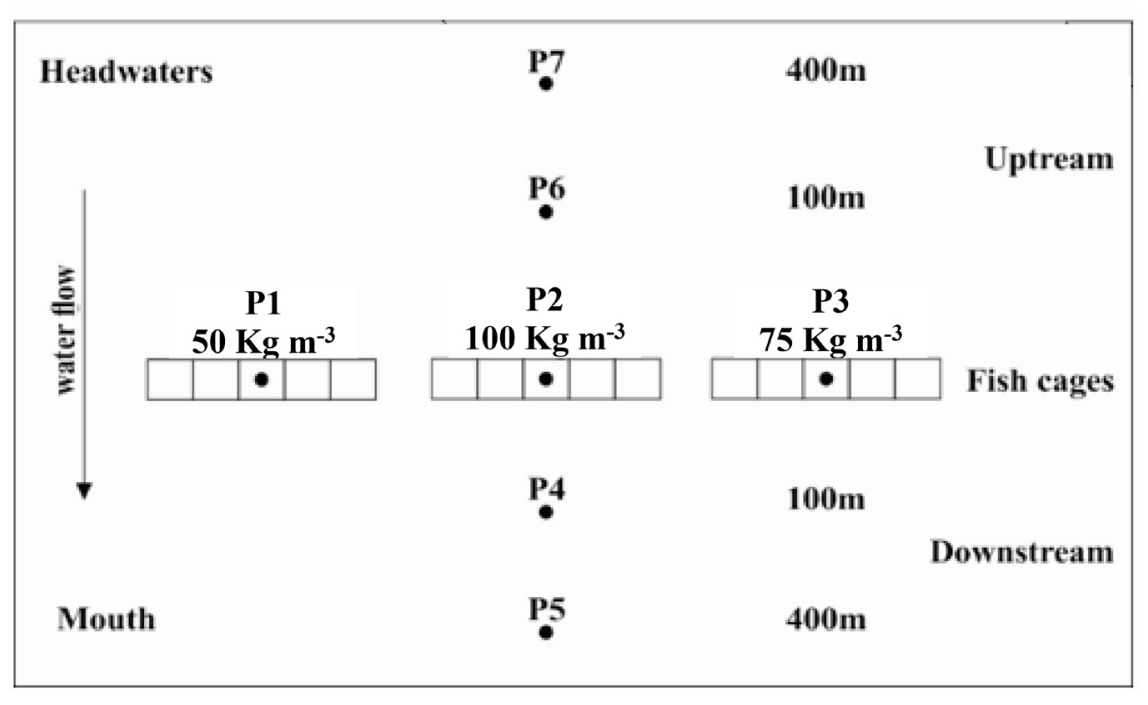

\author{
Figure 2. Schematic \\ representation of the point \\ distribution at the sampling \\ sites (upstream, downstream \\ and net cages).
}


gradient and detect changes on the distributions of species. This analysis uses the value IndVal (Value Indicator) to identify these points of change. When the value obtained by IndVal is less than 0.05 and values of purity and reliability are greater than 0.95 a species is considered significantly associated with a positive $(z+)$ or negative (z-) response. To determine the significant indicator taxa with high precision, data was permutated 500 times, and IndVal < 0.05 were retained. TITAN was implemented with the TITAN2 package (Baker \& King 2010) of the $R$ Environment (R Development Core Team 2018) using the untransformed abundance of taxa with $\geq 3$ occurrences (King \& Baker 2014).

\section{RESULTS}

We identified 45 species (34 cladocerans and 11 copepods). The oligotrophic habitat presented the lower number of species (14 cladocerans and 10 copepods) when compared to the eutrophic habitat (30 cladocerans and 9 copepods). Species composition has also differed significantly among habitats ( $p=0.001$, PERMANOVA).

Species more frequently found in the Guairacá River were Moina minuta and Notodiaptomus henseni, while those more frequently found in the Corvo River were Ceriodaphnia silvestrii and Notodiaptomus henseni. Furthermore, we observed that Notodiaptomus henseni (466489.5) and Ceriodaphnia silvestrii (201015.8) presented higher abundance values in Corvo River, and Ceriodaphnia cornuta (834045) and Moina minuta (316252) were most abundant in the Guairacá River.

Chlorophyll-a concentration was higher in the eutrophic (varying between 9.7 and $0.8 \mathrm{\mu g} \mathrm{L}^{-1}$, with mean $2.9 \mathrm{\mu g} \mathrm{L}^{-1}$, and coefficient of variation of $57 \%$ ) than in oligotrophic habitats (varying between 5.3 and $0.4 \mu \mathrm{g} \mathrm{L^{-1 }}$, with mean $2.3 \mu \mathrm{g} \mathrm{L}^{-1}$ and coefficient of variation of $54 \%$ ).

Through TITAN, we identified significant points of change in the frequency of occurrence and abundance of species in response to chlorophyll-a concentration only in the eutrophic habitat (Table I).

In the eutrophic habitat, we identified the point of change for negative response (z-) to chlorophyll- $a$ at $1.37 \mu \mathrm{g} \mathrm{L^{-1 }}$, while the point of change for positive response $\left(\mathrm{z}^{+}\right)$was observed at a concentration of $3.41 \mu \mathrm{g} \mathrm{L}^{-1}$ (Figure $3 \mathrm{a}$ ).

The frequency of occurrence and abundance of species that indicated negative response (z-) started to decline at the chlorophyll-a concentration of around $1.8 \mu \mathrm{g} \mathrm{L}^{-1}$, and continued to decrease until approximately $4.85 \mathrm{\mu g} \mathrm{L}^{-1}$. On the other hand, approximately, at the chlorophyll-a concentration of $2 \mu \mathrm{g} \mathrm{L}^{-1}$ we observed a gain of species that indicated positive response $\left(z^{+}\right)$, which continued to occur until the concentration of $5 \mu \mathrm{g} \mathrm{L}^{-1}$ (Figure $3 \mathrm{a}$ ).

We identified nine species considered as indicators of change in community composition,

Table I. TITAN results for cladoceran and copepod species in response to variation in chlorophyll- $a$ concentrations in oligotrophic and eutrophic habitats Obs. = Observed change point; $5 \%, 10 \%, 50 \%, 90 \%$ and $95 \%=$ quartiles thresholds. Direction of the response given by z- (negative) and $z+$ (positive).

\begin{tabular}{|c|c|c|c|c|c|}
\hline & \multirow{2}{*}{$\begin{array}{l}\text { Predictive } \\
\text { variable }\end{array}$} & \multirow[t]{2}{*}{ Method } & \multicolumn{3}{|c|}{ Point of change } \\
\hline & & & Obs. & $5 \%$ & $95 \%$ \\
\hline \multirow{2}{*}{ 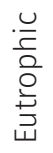 } & \multirow{2}{*}{ Chlorophyll-a } & $z^{-}$ & 1.37 & 1.02 & 3.41 \\
\hline & & $z^{+}$ & 3.41 & 1.71 & 4.85 \\
\hline \multirow{2}{*}{ 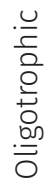 } & \multirow{2}{*}{ Chlorophyll-a } & z- & 1 & - & - \\
\hline & & $z^{+}$ & 7 & - & \\
\hline
\end{tabular}


with significant responses to variation in chlorophyll-a $(p<0.05)$, most of them showing positive responses $(n=6)$. Species with highest magnitude of positive responses, varying between 3.5 and $5 \mu \mathrm{g} \mathrm{L}^{-1}$, were Bosmina hagmanni, Argyrodiaptomus azevedoi and Thermocyclops minutus. We identified negative responses to chlorophyll-a concentration for three species, with highest magnitude of negative response, around $3 \mu \mathrm{g} \mathrm{L}^{-1}$, presented by Bosminopsis deitersi (Figure 3b).

\section{DISCUSSION}

Our results evidence that net cage fish farming affected differently the microcrustacean community structure of different habitats in the Rosana Reservoir. Species composition differed significantly between the studied habitats, but only in the eutrophic habitat changes in species frequency and abundance were attributed to chlorophyll-a concentration.
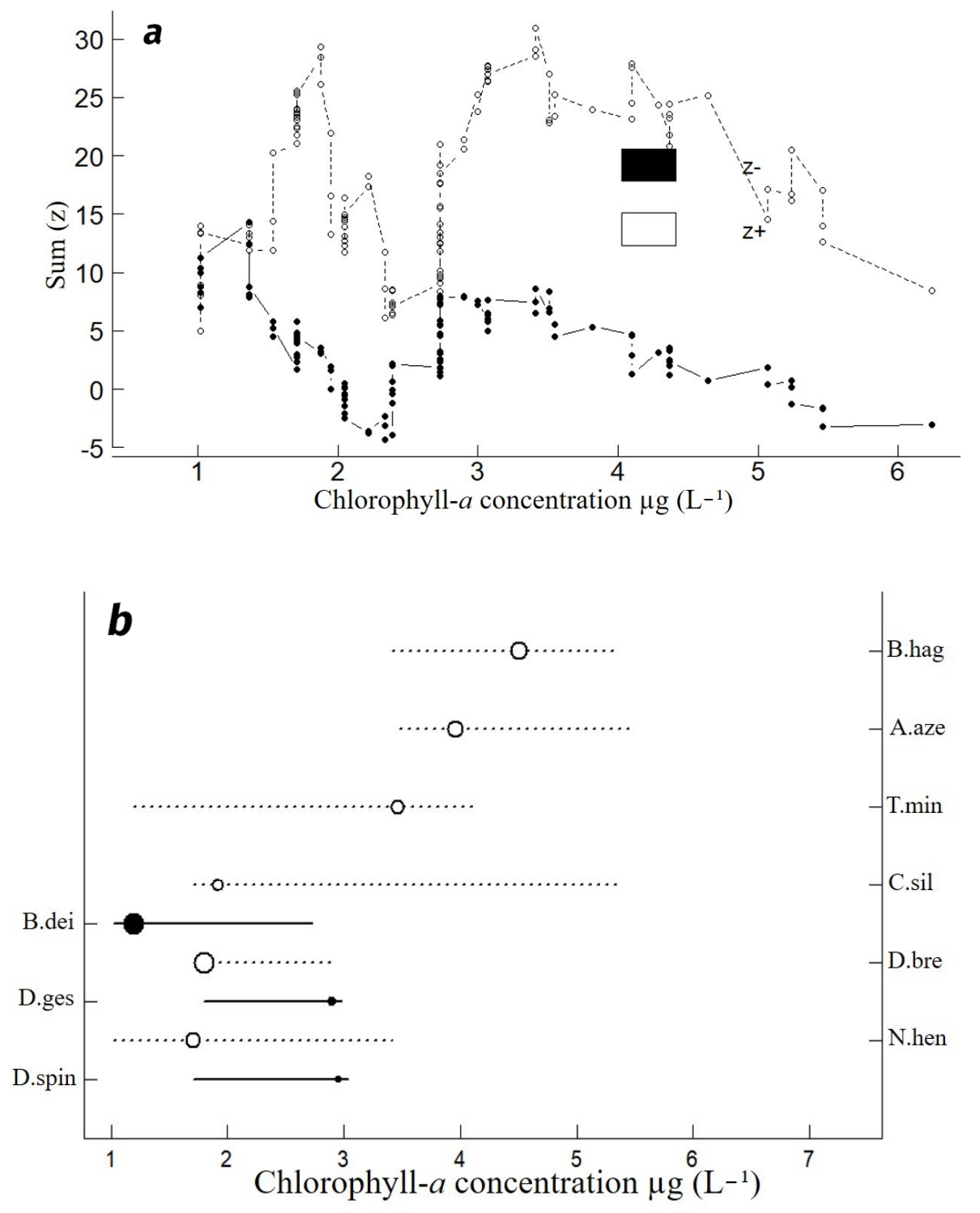

Figure 3. Graphical representation based on the analysis of threshold indicators (TITAN) for zooplankton species that showed significance throughout the chlorophyll-a concentration variation in the eutrophic environment (3a). Species that are negatively (z-) (black circles) and positively associated $(z+)$ (white circles) suggest a negative and positive response to increasing chlorophyll-a (3b) concentrations. The diameter of the circle is proportional to the magnitude of the response. 
Different values of nutrient and turbidity among habitats generate differences in composition and availability of resources (Freire \& Pinto-Coelho 1986, Mantovano et al. 2019). These variables affect the type of algae and consequently the quality of available feeding resources. Thus, chlorophyll-a variation affects the structure of zooplankton communities (Dodson et al. 2000, Barnett \& Beisner 2007, Simões et al. 2013a) and alter trophic relationships between producers and consumers (Simões et al. 2012, Figueiredo et al. 2015).

According with Matsumura-Tundisi \& Tundisi (2005) the plankton composition in freshwater aquatic ecosystems are dependent on various factors such as the environment trophic variables, like chlorophyll-a. Previous studies developed in oligotrophic and eutrophic environments pointed that local factors associated to the availability of feeding resources determine the composition of the zooplankton community, as they promote or limit the occurrence of certain species (Hutchinson 1957, Simões et al. 2013b). Differences pointed by our results in the composition among habitats represent a response to the variability of environmental conditions and different degrees of trophy (Mantovano et al. 2019). Therefore, changes in the composition of microcrustacean species due to chlorophyll-a alterations are related to food availability to aquatic organisms (Aranguren-Riaño et al. 2011, Schwind et al. 2017). This availability is considered as a predominant environmental filter to the structure of plankton communities (Arrieira et al. 2015, Schwind et al. 2017, Mantovano et al. 2019). Thus, the capacity of each species to compete and acquire resources becomes an important proxy to minimize competitive exclusion (Paidere et al. 2007, Simões et al. 2012).
Habitats with high chlorophyll-a concentration suggest a higher availability of phytoplankton biomass (Borges et al. 2010). However, quality or size of the available resource may not favour their predation, and consequently the establishment of zooplankton species (Ferrão-Filho et al. 2000, Ghadouani et al. 2003). Previous studies realized in oligotrophic environments related an inverse relationship in the phytoplankton/zooplankton dynamics. These studies observed that, in conditions of high phytoplankton abundance, there was an expressive reduction in cladoceran and copepod density, explained by the low quality of available feeding resources (Borges et al. 2010, Dias et al. 2011).

In the eutrophic habitat, this fact reflected in modifications on the structure of the microcrustacean community. The characteristics of each species, as well as their responses to environmental variation, are determinant to the comprehension of the mechanisms that determine community changes, as they are directly associated to the limits and requirements of each group of organisms (Poff 1997, Schwind et al. 2019).

Our results corroborate with the information that planktonic microcrustaceans are indicators of environmental quality. In the eutrophic habitat, B. hagmanni presented an increase in frequency of occurrence and abundance according to the increase in chlorophyll-a concentration, while $B$. deitersi presented an opposing response. Other studies found a relationship between abundance of species of the family Bosminidae and reservoir trophy. These studies found $B$. hagmanni was dominant in eutrophic reservoirs and $B$. deitersi was more abundant in oligotrophic reservoirs (Sartori et al. 2009, Santos et al. 2011). 
Calanoida copepods present high sensitivity to changes in environmental characteristics (Matsumura-Tundisi \& Tundisi 2003). Furthermore, they present functional traits as filtrating mechanisms, a common characteristic of herbivore zooplankton, which makes them very plastic with respect to feeding resources (Perbiche-Neves et al. 2014). This characteristic allows an opportunistic selecting behaviour, depending on available resources and discriminating low quality resources when there is high abundance of high quality food (De Mott 1999). Thus, the eutrophic habitat may have propitiated favourable conditions to the establishment of Argyrodiaptomus azevedoi a species that responded positively to chlorophyll-a.

Species with high potential of response of the analysed variable differed in relation to size spectrum, as we registered both small cladocerans as B. hagmanni and B. deitersi and large copepods as A. azevedoi. According to Sampaio et al. (2002) and Rietzler et al. (2002) these species, of large size, can be used as indicators of trophic state in freshwater ecosystems. Studies have demonstrated a relationship between body size of aquatic organisms and availability of feeding resources (Jeppesen et al. 2010, Bomfim et al. 2018, Mantovano et al. 2019). Habitats with high productivity have a higher quantity of available energetic resources (Ortega-Mayagoitia et al. 2011). This favours the colonization of small planktonic organisms (Havens 1998, Bomfim et al. 2018, Mantovano et al. 2019), as they invest in growth and reproduction, reflecting in population increase and community diversity (Allan 1976, Dodson 1992).

This relationship explains the higher richness found in eutrophic habitats, as well as the positive response of $B$. hagmanni, a smallsized cladoceran (Dias et al. 2011), to increased chlorophyll-a concentration, even if this was not a linear relationship. On the other hand, B. deitersi, also a small-sized species, was not favoured by the increase in resource availability. This result suggests a competition between species of the same family (Bosminidae), from which the last species gets prejudiced. Furthermore, A. azevedoi and T. minutus also presented positive responses to chlorophyll-a increase. These copepods are larger than Bosminidae and very efficient in food uptake through filtration (Perbiche-Neves et al. 2016). However, B. hagmanni, presenting longer antennae (Bleiwas \& Stokes 1985, Dodson et al. 2009), seems to be more efficient in filtration than B. deitersi, which intensifies competitive disadvantages between species. The occurrence T. minutus and A. azevedoi was also registered in the series of a six reservoirs located in the Tietê River, due to agricultural fertilizers and discharge of non-treated wastewater, these sites showed a eutrophic condition in the spatial gradient (Matsumura-Tundisi \& Tundisi 2005). Due the cage fish, the state trophic local is altered determining the richness and composition of organisms, within environments mainly of meso and eutrophics characteristics happen consequences in which the zooplanktonic community.

The pattern of frequency of occurrence and abundance of these four species was unimodal when related to chlorophyll-a. Food quality and size may be limiting factors. Previous studies developed in this same area verified that the increase in zooplankton predation pressure on small phytoplankton species favoured cyanobacteria (Borges et al. 2010, Dias et al. 2011). These algae are known for their negative effect on the development and growth of the zooplankton community for being nonpalatable, hardly digested and presenting toxins (Chorus \& Bartram 1999, Ferrão-Filho et al. 2000, 
Ghadouani et al. 2003, Codd et al. 2005, Borges et al. 2010).

We showed that even with nutrient intake through fish farming in net cages, the composition of the microcrustacean community in oligotrophic habitats remains different from that of eutrophic habitats. Nutrient input in the water column is recognized as one of the main eutrophication processes close to fish farming net cages (Negreiros et al. 2009, Dias et al. 2011). These results are corroborated by ecological studies made by Silva \& Matsumura-Tundisi (2005) and Landa et al. (2007).

We observed that, in the eutrophic habitat, TITAN did not verify significant relationships. Caution is necessary when interpreting the influence of this activity on the environment on which it is inserted. Aspects as study duration, morphological characteristics of the environment, among others, may have contributed to microcrustacean community resilience and reduced variation in chlorophyll-a concentrations in the water. Nevertheless, results found through TITAN suggest that this tool is effective to evaluate changes in chlorophyll-a concentration, once that it allows the evaluation of the entire gradient, without categorizing it, and enables the visualization of community thresholds and main indicator species.

Frequency and abundance of the microcrustacean community demonstrated that the operation of tanks in the eutrophic habitat presents a potential negative effect on indicator species. Thus, the installation of net cages is capable of altering community structure and, consequently, affecting other trophic levels due to loss of ecosystem functions (e.g. phytoplankton -Challouf et al. 2017, Guo \& Li 2003 for zoobentonics). TITAN has identified thresholds that influence the distribution of the indicator species, and of chlorophyll-a concentrations. These alterations occurred due to the relationship between these species and their responses to the quantity and quality of the available feeding resources.

At last, we suggest for more studies in other reservoirs with different trophic conditions. This would enable a larger amplitude of results on the impact of net cage activity on the structure of the zooplankton community, once that these organisms are a link between producers and consumers in the pelagic food chains.

\section{Acknowledgments}

The present study was supported by (CAPES/PROEX), an Brazilian Government Agency for the training of human resources. The authors would like to thank Dra. Liliana Rodrigues for the suggestions; Nupélia and the Postgraduation Program for logistic support; Coordenação de Aperfeiçoamento de Pessoal de Nivel Superior (CAPES), and Conselho Nacional de Desenvolvimento Científico e Tecnológico (CNPq) for scholarships and productivity scholarship for CCB.

\section{REFERENCES}

ALLAN JD. 1976. Life history patterns in zooplankton. Amer Nat 110: 165-176.

ALVES RCP \& BACCARIN AE. 2005. Efeito da produção de peixes em tanques-rede sobre sedimentação de material em suspensão e de nutrientes no córrego da Arribada (UHE Nova Avanhandava, Baixo Rio Tietê, São Paulo). In: Nogueira MG, Henry R and Jorcin A (Eds), Ecologia de reservatórios: impactos potenciais, ações de manejo e sistemas em cascata. São Carlos: Rima, p. 329-347.

ARANGUREN-RIAÑO N, GUISANDE C \& OSPINA R. 2011. Factors controlling crustacean zooplankton species richness in Neotropical lakes. J Plank Resh 33(8): 1295-1303.

ARRIEIRA RL, SCHWIND LTF, BONECKER CC \& LANSAC-TÔHA FA. 2015. Use of functional diversity to assess determinant assembly processes of testate amoebae community. Aquat Ecol 49: 561-571.

BAKER ME \& KING RS. 2010. A new method for detecting and interpreting biodiversity and ecological community thresholds. Met Ecol Evol 1: 25-37.

BARNETT A \& BEISNER BE. 2007. Zooplankton biodiversity and lake trophic state: explanations invoking resource abundance and distribution. Ecology 88: 1675-1686. 
BEVERIDGE MCM. 2004. Cage Aquaculture, 3rd ed., Oxford, UK: Blackwell Publishing Ltd, 368 p.

BLEIWAS AH \& STOKES PM. 1985. Collection of large and small food particles by Bosmina. Limnol Oceanog 30: 1090-1092.

BOMFIM FF, BRAGHIN LSM, BONECKER CC \& LANSAC-TÔHA FA. 2018. High food availability linked to dominance of small zooplankton in a subtropical floodplain. Int Rev Hydrobiol 103: 1-2.

BORGES PAF, TRAIN S, DIAS JD \& BONECKER CC. 2010. Effects of fish farming on plankton structure in a Brazilian tropical reservoir. Hydrobiologia 649: 279-291.

BORGES PAF, TRAIN T \& RODRIGUES LC. 2008. Estrutura do fitoplâncton, em curto período de tempo, em um braço do reservatório de Rosana (Ribeirão do Corvo, Paraná, Brasil). Acta Scient Biol Sci 30: 57-65.

BOTTRELL HH, DUNCAN A, GLIWICZ ZM, GRYGIEREK E, HERZIG A, HILLBRICHT-ILKOWSKA A, KURASAWA H, LARSSON P \& WEGLENSKA T. 1976. A review of some problems in zooplankton production studies. Norw J Zool 24: 419-456.

CAO X, WANG J, LIAO J, SUN J \& HUANG Y. 2016. The threshold responses of phytoplankton community to nutrientgradient in a shallow eutrophic Chinese lake. Ecol Indic 61: 258-267.

CESP - COMPANHIA ENERGÉTICA DE SÃO PAULO. 1998. Conservação e manejo nos reservatórios: limnologia, ictiologia e pesca. São Paulo: Série Divulgação e Informação, 166 p.

CHALLOUF R, HAMZA A, MAHFOUDHI M, GHOZZI K \& BRADAI MN. 2017. Environmental assessment of the impact of cage fish farming on water quality and phytoplankton status in Monastir Bay (Eastern Coast of Tunisia). Aquac Intern 25(6): 2275-2292.

CHORUS I \& BARTRAM J. 1999. Toxic Cyanobacteria in Water: A Guide to Their Public Health Consequences, Monitoring and Management. London: WHO E \& FN Spon, 432 p.

CODD GA, MORRISON LF \& METCALF JS. 2005. Cyanobacterial toxins: risk management for health protection. Toxic Appl Pharmac 203: 264-272.

CYRINO JEP \& KUBITZA F. 1996. Piscicultura. Coleção agroindústria, vol. 8. Cuiabá: Editora Sebrae, MT, 86 p.

DE MOTT WR. 1999. Foraging strategies and growth inhibition in five daphnids feeding on mixture of a toxic cyanobacterium and green alga. Fresh Biol 42(2): 263-274.

DIAS JD, TAKAHASHI EM, SANTANA NF \& BONECKER CC. 2011. Impact of fish cage-culture on the community structure of zooplankton in a tropical reservoir. Iheringia Sér Zool 101: 75-84.

DODSON SI. 1992. Predicting crustacean zooplankton species richness. Limnol Oceanog 37: 848-856.

DODSON SI, ARNOTT SE \& COTTINGHAM KL. 2000. The relationship in lake communities between primary productivity and species richness. Ecology 81: 2662-2679.

DODSON SL, CÁCERES CE \& ROGERS DC. 2009. Cladocera and other Branchiopoda. In James H. Thorp. Ecology and Classification of North American Freshwater Invertebrates ( $3^{\text {rd }}$ ed.). Academic Press, p. 773-828.

DUSSART BH. 1984. Some Crustacea Copepoda from Venezuela. Hydrobiologia 113: 15-23.

ELMOOR-LOUREIRO MAL. 1997. Manual de identificação de cladóceros límnicos do Brasil. Brasília: Editora Universa, $155 \mathrm{p}$.

FERRÃO-FILHO AS, AZEVEDO SMFO \& DEMOTT RW. 2000. Effects of toxic and non-toxic cyanobacteria on the life history of tropical and temperate cladocerans. Fresh Biol 45: $1-19$.

FIGUEIREDO BRS, MORMUL RP \& BENEDITO E. 2015. Structural complexity and turbidity do not interact to influence predation rate and prey selectivity by a small visually feeding fish. Mar Fresh Res 66: 170-176.

FREIRE BM \& PINTO-COELHO RM. 1986. Composição e Distribuição Horizontal do Zooplâncton no Reservatório de Vargens das Flores, Betim/Contagem, Minas Gerais. Cien Cult 38(5): 919-927.

FURLANETO FPB, AYROZA DMMR \& AYROZA LMS. 2006. Custo e rentabilidade da produção de tilápia (Oreochromis spp.) em tanques-rede no médio Paranapanema, Estado de São Paulo, safra 2004/05. Informações Econômicas SP 36: 63-69.

GHAdOUANI A, PINEL-ALLOUL B \& PREPAS EE. 2003. Effects of experimentally induced cyanobacterial blooms on crustacean zooplankton communities. Freshw Biol 48: 363-381.

GOLTERMAN HL, BAKELS CC \& JAKOBSMOGELEIN J. 1969. Availability of mud phosphates for the growth of algae. Verh Int Vez Limnol 17: 467-479.

GUO L \& LI Z. 2003. Effects of nitrogen and phosphorus from fish cage-culture on the communities of a shallow lake in middle Yangtze River basin of China. Aquaculture 226: 201-212.

HALWART M, SOTO D \& ARTHUR JR. 2007. Cage aquaculture: regional reviews and global overview. FAO Fish Tech Pap, $259 \mathrm{p}$. 
HAVENS KE. 1998. Size structure and energetics in a plankton food web. Oikos 81: 346-358.

HUTCHINSON GE. 1957. Concluding remarks. Population studies. Anim Ecol Demogr 22: 415-427.

JEPPESEN E ET AL. 2010. Impacts of climate warming on lake fish community structure and potential effects on ecosystem function. Hydrobiologia 646: 73-90.

JÚLIO JÚNIOR HF, THOMAZ SM, AGOSTINHO AA \& LATINI JD. 2005. Distribuição e caracterização dos reservatórios. In: Rodrigues L, Thomaz SM, Agostinho AA and Gomes LC (Org). Biocenoses em reservatórios: padrões espaciais e temporais, São Carlos: Rima, p. 1-16.

KING R \& BAKER ME. 2014. Use, misuse, and limitations of Threshold Indicator Taxa Analysis (TITAN) for natural resource management. In: Application of threshold concepts in natural resource decision making. Springer, New York, NY, p. 231-254.

KOSTE W. 1978. Rotatoria die Rädertiere Mitteleuropas begründet von Max Voight, 673 p.

LANDA GG, BARBOSA, FAR, RIETZLER AC \& MAIA BARBOSA P. 2007. Thermocyclops decipiens (Kiefer, 1929) (Copepoda, Cyclopoida) as Indicator of Water Quality in the State of Minas Gerais, Brazil. Braz Arch Biol 50(4): 695-705.

LANSAC-TÔHA FA, VELHO LFM, HIGUTI J \& TAKAHASHI EM. 2002. Cyclopidae (Crustacea, Copepoda) from the upper Paraná River floodplain, Brazil. Braz J Biol 62: 125-133.

LEMKE AM \& BENKE AC. 2009. Spatial and temporal patterns of microcrustacean assemblage structure and secondary production in a wetland ecosystem. Fresh Biol 54: 1406-1426.

MANTOVANO T, BRAGHIN LSM, SCHWIND LTF, TIBURCIO VG, BONECKER CC \& LANSAC-TÔHA FA. 2019. Zooplankton communities show contrasting productivity variables thresholds in dammed and undammed systems. Limnética 38(2): 669-682.

MARTIN J, RUNGE MC, NICHOLS JD, LUBOW BC \& KENDALL WL. 2009. Structured decision making as a conceptual framework to identify thresholds for conservation and management. Ecol App 19: 1079-1090.

MATSUMURA-TUNDISI T \& TUNDISI JG. 2003. Calanoida (Copepoda) species composition changes in the reservoirs of São Paulo State (Brazil) in the last twenty years. Hydrobiologia 504(1-3): 215-222.

MATSUMURA-TUNDISI T \& TUNDISI JG. 2005. Plankton richness in a eutrophic reservoir (Barra Bonita Reservoir, SP, Brazil). Hydrobiologia 542(1): 367-378.
NEGREIROS NF, ROJAS NE, ROCHA O \& WISNIEWSKI MJ. 2009. Composition, diversity and short-term temporal fluctuations of zooplankton communities in fish culture ponds (Pindamonhangaba), SP. Braz J Biol 69(3): 785-794.

OKSANEN J, BLANCHET FG, KINDT R, LEGENDRE P, O'HARA B \& SIMPSON GL. 2018. Vegan: Community Ecology Package. R package version 1: 17-3.

OMORI M \& IKEDA T. 1984. Methods in Marine Zooplankton Ecology. New York: J Wiley \& Sons, 332 p.

ORTEGA-MAYAGOITIA E, CIROS-PEREZ I \& SANCHEZ-MARTINEZ M. 2011. A story of famine in the pelagic realm: temporal and spatial patterns of food limitation in rotifers from an oligotrophic tropical lake. J Plankt Res 33: 1574-1585.

PAGIORO TA, VELHO LFM, LANSAC-TÔHA FA, PEREIRA DG \& NAKAMURA AKS. 2005. Influência do grau de trofia sobre os padrões de abundância de bactérias e protozoários planctônicos em reservatórios do estado do Paraná. In: Rodrigues L, Thomaz SM, Agostinho AA and Gomes LC (Eds), Biocenose em Reservatórios: padrões espaciais e temporais, Maringá: UEM/Nupelia, p. 47-56.

PAIDERE J, GRUBERTS D, ŠKUTE A \& DRUVIETIS I. 2007. Impact of two different flood pulses on planktonic communities of the largest floodplain lakes of the Daugava River (Latvia). Hydrobiologia 592(1): 303-314.

PERBICHE-NEVES G, BOXSHALL GA, NOGUEIRA MG \& ROCHA CE. 2014. Trends in planktonic copepod diversity in reservoirs and lotic stretches in a large river basin in South America. Marine and Freshw Res 65(8): 727-737.

PERBICHE-NEVES G, PORTINHO JL, FERREIRA RAR \& NOGUEIRA MG. 2016. Increases in microcrustaceans (Cladocera and Copepoda) associated with phytoplankton peaks in tropical reservoirs. Trop Ecol 57(3): 523-532.

POFF NL. 1997. Landscape filters and species traits: towards mechanistic understanding and prediction in stream ecology. J Nort Amer Benth Soc 16: 391-409.

R DEVELOPMENT CORE TEAM. 2018. R: Language and environment for statistical computing foundation for Statistical Computing. Version 3.2.2.

REID JW. 1985. Chave de identificação e lista de referências bibliográficas para as espécies continentais sul-americanas de vida livre da ordem Cyclopoida (Crustacea, Copepoda). Bol Zoo 9: 17-143.

RIETZLER AC, MATSUMURA-TUNDISI T \& TUNDISI JG. 2002. Life cycle, feeding and adaptive strategy implications on on the co-occurence of Argyrodiaptomus furcatus and Notodiaptomus iheringi in Lobo-Broa reservoir (SP, Brazil). Braz J Biol 62: 93-105. 
SAMPAIO EV, ROCHA O, MATSUMURA-TUNDISI T \& TUNDISI JG. 2002. Composition and abundance of zooplankton in the limnetic zone of seven reservoirs of the Paranapanema River, Brazil. Braz J Biol 62(3): 525-545.

SANTOS FV, LANSAC-TOHA FA \& BONECKER CC. 2011. Estrutura das assembleias de cladóceros em reservatórios nos estados de São Paulo e Paraná: gradientes espaciais e grau de trofia. Oecol Aust 15(3): 494-510.

SANTOS R, ROCHA G, ROCHA O \& WISNIEWSKI MJS. 2009. Influence of net cage fish cultures on the diversity of the zooplankton community in the Furnas hydroelectric reservoir, Areado. MG: Brazil. Aquac Res 40: 753-761.

SANTOS-SILVA EN. 2000. Revisão das espécies do “complexo nordestinus" (Wright, 1935) de Notodiaptomus Kiefer (1936) (Copepoda: Calanoida: Diaptomidae). São Paulo: Universidade de São Paulo, 196 p.

SARTORI LPA, NOGUEIRA MGA, HENRY RA \& MORETTO EM. 2009. Zooplankton fluctuations in Jurumirim Reservoir (São Paulo, Brazil): a three-year study. Braz J Biol 69(1): 1-18.

SCHWIND LTF, ARRIEIRA RL, MANTOVANO T, VELHO LFM, BONECKER CC \& LANSAC-TÔHA FA. 2019. Testate amoebae as indicators of temporal variation in the concentration of suspended inorganic material in environments influenced by dams. Intern Rev Hydrob 1: e1801949.

SCHWIND LTF, ARRIEIRA RL, SIMÕES NR, BONECKER CC \& LANSAC-TÔHA FF. 2017. Productivity gradient affects the temporal dynamics of testate amoebae in a neotropical floodplain. Ecol Ind 78: 264-269.

SILVA WM \& MATSUMURA-TUNDISI T. 2005. Taxonomy,ecology, and geographical distribution of the species of the genus Thermocyclops Kiefer, 1927 (Copepoda, Cyclopoida) in São Paulo State, Brazil, with description of a new species. Braz J Biol 65(3): 521-531.

SIMÕES NR, DIAS JD, LEAL CM, BRAGHIN LSM, LANSAC-TÔHA FA \& BONECKER CC. 2013a. Floods control the influence of environmental gradients on the diversity of zooplankton communities in a neotropical floodplain. Aquat Sci 75: 607-617.

SIMÕES NR, LANSAC-TÔHA FA \& BONECKER CC. 2013b. Drought disturbances increase temporal variability of zooplankton community structure in floodplains. Int Rev Hydrobiol 98: 24-33.

SIMÕES NR, LANSAC-TÔHA FA, VELHO LFM \& BONECKER CC. 2012. Intra and inter-annual structure of zooplankton communities in floodplain lakes: a long-term ecological research study. Rev Biol Trop 60: 1819-1836.

SIMÕES NR, NUNES AH, DIAS JD, LANSAC-TÔHA FA, VELHO LFM \& BONECKER CC. 2015. Impact of reservoirs on zooplankton diversity and implications for the conservation of natural aquatic environments. Hydrobiologia 758: 3-17.

TIBURCIO VG, ARRIEIRA RL, SCHWIND LTF, BONECKER CC \& LANSAC-TÔHA FA. 2015. Effects of nutrients increase on the copepod community of a reservoir using cages. Acta Limnol Bras 27(3): 265-274.

TÕNNO I, AGASILD H, KÕIV T, FREIBERG R, NÕGES P \& NÕGES T. 2016. Algal Diet of Small-Bodied Crustacean Zooplankton in a Cyanobacteria-Dominated Eutrophic Lake. PLoS ONE 11(4): 1-17.

WETZEL RG \& LIKENS GE. 1991. Limnological analyses. New York: Springer-Verlag, $3^{\text {rd }}$ ed., 429 p.

\section{How to site}

TIBÚRCIO VG, MANTOVANO T, DA SILVA JVF \& BONECKER CC. 2021. Influence of the chlorophyll- $a$ gradient on the community structure of plankton microcrustaceans (Cladocera and Copepoda) in a Neotropical reservoir. An Acad Bras Cienc 93: e20190379. DOI 10.1590/0001-3765202120190379.

Manuscript received on March 29, 2019;

accepted for publication on September 24, 2019

VANESSA G. TIBÚRCIO 1

https://orcid.org/0000-0001-6266-5743

TATIANE MANTOVANO ${ }^{2}$

https://orcid.org/0000-0002-6583-4554

\section{JOÃO V.F. DA SILVA ${ }^{1}$}

https://orcid.org/0000-0002-1742-995X

\section{CLAUDIA C. BONECKER ${ }^{2}$}

https://orcid.org/0000-0003-4338-9012

${ }^{1}$ Programa de Pós-Graduação em Biologia Comparada (PGB), Universidade Estadual de Maringá (UEM), Departamento de Biologia, Av. Colombo, 5790, Campus Universitário, 87020-900 Maringá, PR, Brazil

${ }^{2}$ Programa de Pós-Graduação em Ecologia de Ambientes Aquáticos Continentais (PEA), Universidade Estadual de Maringá (UEM), Núcleo de Pesquisas em Limnologia Ictiologia e Aquicultura (Nupélia), Av. Colombo, 5790, Campus Universitário, 87020-900 Maringá, PR, Brazil 
Correspondence to: Vanessa G. Tibúrcio

E-mail:vanessinha.g7@gmail.com

\section{Author contributions}

Vanessa G. Tibúrcio analyzed the samples, analyzed the data, wrote and revised the manuscript. Claudia C. Bonecker acted as research supervisor, outlined the study, supervised and revised the manuscript for intellectual content. Tatiane Mantovano and João V. F. da Silva contributed to the writing, revision and editing of the material. All authors discussed the results and decided to approve the final version of the manuscript.

(cc) BY 